удк 336.2

DOI https://doi.org/10.32837/pyuv.v0i5(34).660

\author{
А.О.Сазонова \\ orcid.org/0000-0002-6542-3309 \\ помічник судді \\ Касаційного адміністративного суду України
}

\title{
ДО ВИЗНАЧЕННЯ ЗМІСТУ ПОНЯТТЯ «НЕЗАЛЕЖНА ПРОФЕСІЙНА ДІЯЛЬНІСТЬ»
}

Постановка проблеми. Податки формують фінансовий базис держави, забезпечуючи основні надходження до державного бюджету та акумулюючи грошові ресурси для фінансування видатків. Фіскальна політика також є дієвим інструментом державного регулювання економіки. При цьому держава цілеспрямовано вживає заходів щодо легалізації майна і діяльності, які підлягають оподаткуванню, в тому числі й діяльності так званих «самозайнятих громадян». Подальше розроблення проблем оподаткування самозайнятих громадян, і в тому числі осіб, які здійснюють незалежну професійну діяльність, забезпечить легітимізацію їхньої діяльності та захист їхніх інтересів, а також забезпечить зростання доходів держави в цілому і рівня життя громадян зокрема.

Варто зазначити, що податкові правовідносини завжди вторинні, адже вони породжуються, наприклад, цивільно-правовими або трудовими правовідносинами. У нашому випадку йдеться про правовідносини, що виникають у процесі здійснення незалежної професійної діяльності. Оскільки вичерпний перелік видів такої діяльності чинним законодавством не передбачений, надзвичайно важливим, на нашу думку, є дослідження її сутності та уточнення поняття.

Стан дослідження. Теоретичні та практичні аспекти формування фіскальної політики та визначення правового статусу учасників податкових правовідносин досліджували зарубіжні й вітчизняні науковці, зокрема: В. Андрущенко, Я. Берназюк, 3. Варналій, О. Василик, Д. Вілсон, О. Воронкова, С. Гізімчук, Ю. Гродецький, О. Данілов, О. Дмитрик, 3. Загиней, Дж. Кейнс, В. Киричко, А. Кізима, В. Кміть, В. Красницький, О. Кришевич, А. Лаффер, В. Мартинюк, В. Мельник, І. Озеров, Д. Рікардо, А. Савченко, В. Тютюгін, Р. Ханова, К. Швабій, Ю. Шиндель тощо. Наукові доробки зазначених учених заклали наукове підгрунтя до визначення податкового статусу самозайнятих осіб. Водночас натепер немає єдності позицій щодо того, які ознаки притаманні незалежній професійній діяльності, адже саме ці ознаки вирізняють осіб, що здійснюють незалежну професійну діяльність, із загального кола самозайнятих осіб.

Постановка завдання. Мета статті - дослідити зміст поняття «незалежна професійна діяльність» у контексті податкових правовідносин.
Виклад основного матеріалу. Станом на 1 квартал 2018 року в Україні було зареєстровано більше 700 тисяч самозайнятих осіб, а у 2020 році - вже близько 2 млн осіб. Зокрема, суттєво зросла кількість фізичних осіб-підприємців на спрощеній системі оподаткування (на початок 2020 року майже на 93,8 тисяч осіб). Водночас самозайняті особи - це не тільки фізичні особи - підприємці.

Так, відповідно до п. 14.1.226. Податкового кодексу України особи, що здійснюють незалежну професійну діяльність, є самостійною підгрупою самозайнятих осіб. До категорії самозайнятих осіб належать також фізичні особи-підприємці. При цьому визначальними ознаками самозайнятої особи як платника податку є те, що вказана особа не є працівником у межах такої підприємницької чи незалежної професійної діяльності [1].

П. 14.1.226. Податкового кодексу України також дає визначення незалежної професійної діяльності, під якою слід розуміти участь фізичної особи в науковій, літературній, артистичній, художній, освітній або викладацькій діяльності, діяльність лікарів, приватних нотаріусів, приватних виконавців, адвокатів, арбітражних керуючих (розпорядників майна, керуючих санацією, ліквідаторів), аудиторів, бухгалтерів, оцінщиків, інженерів чи архітекторів, осіб, зайнятих релігійною (місіонерською) діяльністю, іншою подібною діяльністю за умови, що така особа не є працівником або фізичною особою - підприємцем (за виключенням випадку, передбаченого пунктом 65.9 статті 65 Податкового кодексу України) та використовує найману працю не більш як чотирьох фізичних осіб [1].

Отже, відповідна діяльність характеризується двома обов'язковими ознаками:

- незалежністю, тобто відсутністю підпорядкування з точки зору трудового законодавства, можливістю встановлення трудових відносин з обмеженою кількістю осіб, а також відсутністю іншого податкового статусу (тобто податкового статусу фізичної особи - підприємця);

- професійністю, тобто спеціальною освітою або підготовкою особи, що її здійснює, в т.ч. й отриманням за необхідності необхідних дозволів.

Якщо зміст ознаки «незалежна» достатньо розкритий безпосередньо в п.14.1.226. Податкового кодексу України [1], то ознака «професійна»,на нашу думку, потребує більш детального дослідження. 
Зауважимо, що в розрізі кримінального права законодавець виокремлює «професійну діяльність, пов'язану 3 наданням публічних послуг». Така діяльність, за змістом диспозиції статті 365-2 Кримінального кодексу України [2], здійснюється аудиторами, нотаріусами, оцінювачами, уповноваженими особами або службовими особами Фонду гарантування вкладів фізичних осіб, іншими особами, які не є державними службовцями, посадовими особами місцевого самоврядування, але здійснюють професійну діяльність, пов'язану з наданням публічних послуг, у тому числі послуг експерта, арбітражного керуючого, приватного виконавця, незалежного посередника, члена трудового арбітражу, третейського судді (під час виконання цих функцій), або державними реєстраторами, суб'єктами державної реєстрації прав, державними виконавцями, приватними виконавцями.

При цьому відповідно до частини 1 статті 368-4 Кримінального кодексу України [2] та відповідно до підпункту б) пункту 2 частини 1 статті 3 Закону України «Про запобігання корупції [3] до осіб, професійна діяльність яких пов'язана з наданням публічних послуг, віднесені аудитори, нотаріуси, приватні виконавці, оцінювачі, експерти, арбітражні керуючі, незалежні посередники, члени трудового арбітражу, третейські судді.

Натомість у частині 3 статті 384-1 Кримінального кодексу України [2] наведено такий перелік осіб, що здійснюють професійну діяльність, пов'язану 3 наданням публічних послуг: аудитор, нотаріус, приватний виконавець, експерт, оцінювач, незалежний посередник, арбітр, третейський суддя (цей перелік, як бачимо, не включає таких осіб, як арбітражний керуючий, уповноважена особа або службова особа Фонду гарантування вкладів фізичних осіб, державний реєстратор, суб'єкт державної реєстрації прав, державний виконавець тощо). Необхідно також підкреслити, що поняття «арбітр», застосоване в частині 3 статті 384-1 Кримінального кодексу України [2], не є тотожним до поняття «член трудового арбітражу», яке використано в Законі України «Про запобігання корупції [3].

Частина 2 статті 358 Кримінального кодексу України [2] встановлює кримінальну відповідальність за складання чи видачу приватним підприємцем, аудитором, експертом, оцінювачем, адвокатом, нотаріусом, державним реєстратором, суб'єктом державної реєстрації прав, особою, яка уповноважена на виконання функцій держави щодо реєстрації юридичних осіб, фізичних осіб-підприємців та громадських формувань, державним виконавцем, приватним виконавцем або іншою особою, яка здійснює професійну діяльність, пов'язану з наданням публічних чи адміністративних послуг, завідомо підроблених офіційних документів, які посвідчують певні факти, що мають юридичне значення або надають певні права чи звільняють від обов'язків. 3 такого формулювання диспозиції можуть випливати висновки про те, що законодавець розмежовує публічні та адміністративні послуги, а також про те, що фізична особа-підприємець може здійснювати професійну діяльність, пов'язану з наданням таких послуг. Втім, чи є це вірним?

Відповідно, маємо розглянути поняття «публічні послуги» (зокрема, Закон України «Про запобігання корупції» [3] оперує поняттям «особа, яка надає публічні послуги»).

Документи Європейського союзу визначають публічні послуги як «послуги загального економічного інтересу», що становлять економічну діяльність, котру органи публічної влади визначають як ту, що має особливо важливе значення для громадян, і яка не здійснювалася б, якби не мало місце втручання з боку публічного сектору [4]. Закон Великобританії «Про публічні послуги (ix значення для суспільства)» (2012р.) [5] встановлює, що орган публічної влади, що надає публічні послуги або сприяє їх наданню, зобов'язаний враховувати те, як саме надання публічних послуг обраним їм чином може поліпшити економічне, соціальне і екологічне благополуччя відповідного регіону, де передбачається надання таких послуг, а також зобов'язаний враховувати те, як даний орган публічної влади може діяти, здійснюючи проведення процесу закупівель послуг, з точки зору забезпечення таких поліпшень. Закон Колумбії № 142 (1994р.) «Про створення режиму надання публічних комунальних послуг та про встановлення інших положень" [6] передбачає надання певного роду послуг публічним сектором 3 метою поліпшення якості життя їхніх споживачів, компенсації недостатньої платоспроможності користувачів таких послуг, а також ефективного, постійного і безперервного надання таких послуг. В Австралії федеральним урядом, урядами штатів і територій, а також місцевими органами влади в 1998 році була підписана Хартія надання публічних послуг у полікультурному суспільстві [7], згідно з якою політика надання публічних послуг повинна грунтуватися на забезпеченні рівного доступу і справедливості для того, щоб публічні послуги могли задовольняти потреби осіб з різними мовними і культурними традиціями, даючи їм можливості повною мірою брати участь в економічному, соціальному і культурному житті.

Істотними ознаками публічних послуг на доктринальному рівні пропонують вважати такі:

- послуги пов'язані із задоволенням конкретних партикулярних (дискретних) потреб, сполучених з публічними інтересами;

- предмети послуг історично належать до виключної компетенції публічної влади (в рамках «традиційної» моделі публічного управління), 
або послуги надаються у випадках, коли дефіцит або повна відсутність приватної ініціативи в наданні такого роду послуг за умови їх особливої соціальної або правової важливості змушують публічну владу брати надання цих послуг на себе;

- надання публічних послуг може бути пов'язано з публічним управлінням у декількох формax (надання публічних послуг є інструментом безпосередньо публічного управління, або ж орган публічної влади організовує надання публічних послуг недержавними суб'єктами, забезпечує управління системою надання публічних послуг та ïi диспетчерське обслуговування, здійснює контроль за функціонуванням цієї системи ) [8; 10].

За визначенням А. Савченко, публічні послуги характеризуються такими ознаками, як: спрямованість на захист чи забезпечення умов для реалізації суспільних інтересів, прав та інтересів фізичних або юридичних осіб; визначеність порядку та форми їх надання державою чи органом місцевого самоврядування; породження наслідків правового характеру [11, с. 64].

В. Тютюгін, С. Гізімчук, Ю. Гродецький виділяють такі ознаки публічних послуг: надаються фізичним або юридичним особам; спрямовані на набуття, зміну чи припинення ними прав та/або обов'язків; право на надання таких послуг, їх види, порядок та форма реалізації визначаються відповідними нормативними актами, які виходять від державних органів чи органів місцевого самоврядування; такі послуги спричиняють (породжують) наслідки правового характеру; результати надання таких послуг, як правило, оформлюються офіційним документом [12, с. 510].

В. Киричко вказує, що осіб, які надають публічні послуги, характеризують такі ознаки: їхні повноваження передбачені відповідними законами України; їхні функції належать публічній сфері суспільних відносин і пов'язані з виконанням функцій держави чи місцевого самоврядування; публічна послуга виражається у здійсненні певних повноважень, передбачених законом, на засадах об’єктивності та неупередженості; здійснення повноважень не є реалізацією приватного інтересу особи, яка надає публічні послуги, хоча може здійснюватися на умовах оплати; фактичні результати здійснення особами своїх повноважень, як правило, відображаються в офіційному документі й набувають обов'язкового юридичного значення для всіх суб'єктів правовідносин або лише для визначених законом суб'єктів (наприклад, для сторін спору); прийняті такими особами рішення спричинюють чи здатні спричинити наслідки правового характеру у сфері виконання функцій держави чи місцевого самоврядування (регулювання суспільних відносин у цілому, забезпечення умов для реалізації прав та законних інтересів фізичних чи юридичних осіб, захисту таких прав та інтересів, вирішення спорів (конфліктів) тощо) [13, с. 50-51].

Концепція розвитку системи надання адміністративних послуг органами виконавчої влади, затвердженої розпорядженням Кабінету Міністрів України від 15 лютого 2006 року № 90-р, визначає, що сферу публічних послуг становлять послуги, що надаються органами державної влади, органами місцевого самоврядування, підприємствами, установами, організаціями, які перебувають в їх управлінні [14].

При цьому відповідно до Закону України «Про адміністративні послуги» адміністративна послуга - це результат здійснення владних повноважень суб'єктом надання адміністративних послуг за заявою фізичної або юридичної особи, спрямований на набуття, зміну чи припинення прав та/або обов'язків такої особи відповідно до закону [15].

Стаття 2 вказаного Закону передбачає, що його дія поширюється на суспільні відносини, пов'язані з наданням адміністративних послуг, і не поширюється при цьому на відносини щодо: здійснення державного нагляду (контролю), в тому числі державного контролю за дотриманням законодавства про харчові продукти, корми, побічні продукти тваринного походження, здоров'я та благополуччя тварин; метрологічного контролю і нагляду; акредитації органів з оцінки відповідності; дізнання, досудового слідства; оперативно-розшукової діяльності; судочинства, виконавчого провадження; нотаріальних дій; виконання покарань; доступу до публічної інформації; застосування законодавства про захист економічної конкуренції; здійснення державного регулювання ринків фінансових послуг; провадження діяльності, пов'язаної з державною таємницею; набуття прав на конкурсних засадах; набуття прав стосовно об'єктів, обмежених у цивільному обігу; здійснення державного регулювання у сферах енергетики та комунальних послуг; сертифікації оператора системи передачі відповідно до Закону України «Про ринок електричної енергії»; авторизації електронних майданчиків та прийняття рішення про відключення авторизованих електронних майданчиків від електронної системи закупівель, передбачених Законом України «Про публічні закупівлі»; здійснення дій, пов'язаних охороною прав на об'єкти інтелектуальної власності (винаходи, корисні моделі, промислові зразки, компонування напівпровідникових виробів, торговельні марки (знаки для товарів і послуг), географічні зазначення, об'єкти авторського права і суміжних прав, реєстрація та акредитація організацій колективного управління) [15].

Натомість частина 3 статті 3 того ж Закону передбачає, що до адміністративних послуг також прирівнюється надання органом виконавчої 
влади, іншим державним органом, органом влади Автономної Республіки Крим, органом місцевого самоврядування, їхніми посадовими особами, державним реєстратором, суб'єктом державної реєстрації витягів та виписок із реєстрів, довідок, копій, дублікатів документів та інші передбачені законом діï, в результаті яких суб'єкту звернення, а також об'єкту, що перебуває в його власності, володінні чи користуванні, надається або підтверджується певний юридичний статус та/або факт [15].

Отже, публічні послуги є більш широким поняттям, ніж послуги адміністративні. Останні, зважаючи на положення статті 1 Закону України «Про адміністративні послуги» [15], можуть визначатися як публічні послуги, які надають органи виконавчої влади, інші державні органи, органи влади Автономної Республіки Крим, органи місцевого самоврядування, їхні посадові особи, державні реєстратори, суб’єкти державної реєстрації, уповноважені відповідно до закону надавати адміністративні послуги.

3 урахуванням положень чинного законодавства та наявних наукових позицій Л. Палюх пропонує виділяти такі категорії осіб, які здійснюють професійну діяльність, пов'язану з наданням публічних послуг:

- аудитори, нотаріуси, приватні виконавці, оцінювачі, експерти, арбітражні керуючі, посередники, арбітри, члени трудового арбітражу, третейські судді, уповноважені особи або службові особи Фонду гарантування вкладів фізичних осіб, державні реєстратори, суб’єкти державної реєстрації прав, державні виконавці;

- інші категорії осіб, чітко визначені законом як особи, які здійснюють професійну діяльність, пов' язану з наданням публічних послуг.

Загальною ознакою обох категорії осіб, які здійснюють професійну діяльність, пов'язану з наданням публічних послуг, пропонується визнавати те, що це особи, які не є державними службовцями або посадовими особами органів місцевого самоврядування [16]. Це, на нашу думку, відрізняє професійну діяльність, пов'язану з наданням публічних послуг, від адміністративних послуг, хоча в частині, що стосується державних реєстраторів та суб'єктів державної реєстрації, уповноважених відповідно до закону надавати адміністративні послуги, ці поняття можуть збігатися.

Загалом же слід констатувати, що перелік публічних послуг наразі не є вичерпним і в умовах постійного розвитку законодавства може бути визначений як відкритий.

Натепер не існує єдиної класифікації публічних послуг, оскільки відсутні достатні теоретичні розробки щодо визначення їхніх характеристик. Однак публічні послуги - це та правова категорія, яка реально існує, має стійкі ознаки і вимагає певної систематизації. Насамперед публічні послуги повинні класифікуватися з урахуванням суб’єктів, що їх надають:

1) послуги, що надаються органами державної влади (державні послуги);

2) послуги, що надаються органами місцевого самоврядування (муніципальні послуги);

3) послуги недержавного сектора.

Слід зауважити, що Концепція розвитку системи надання адміністративних послуг органами виконавчої влади, затвердженої розпорядженням Кабінету Міністрів України від 15 лютого 2006 року № 90-р [14], яка визначає сферу публічних послуг, не виокремлює в ній послуг недержавного сектору, хоча власне саме з цією категорією публічних послуг пов'язана незалежна професійна діяльність.

Висновки. У спробі класифікувати незалежну професійну діяльність у контексті питань оподаткування на таку, що пов'язана з наданням публічних послуг, та іншу незалежну професійну діяльність, маємо дійти висновку, що перелік видів незалежної професійної діяльності в рамках обох категорій не є вичерпним. Це, зокрема, свідчить про необхідність законодавчої систематизації публічних послуг, а також урегулювання порядку i стандартів їх надання. Також існує нагальна потреба в більш чіткому розмежуванні правового та, зокрема, податково-правового статусу осіб, що здійснюють незалежну професійну діяльність, і фізичних осіб - підприємців.

\section{1. Податковий кодекс України. URL: https://zakon.rada.gov.ua/laws/show/2755-17}

2. Кримінальний кодекс України. URL: https://zakon.rada.gov.ua/laws/show/234114 \# Text

3. Закон України «Про запобігання корупції. URL: https: / / zakon.rada.gov.ua/laws/show/ 1700-18\#Text

4. Services of General Economic Interest: Opinion Prepared by the State Aid Group of EAGCP / State Aid Group of Economic Advisory Group on Competition Policy. URL: http://ec.europa.eu/competition/state_ aid/legislation/sgei.pdf

5. Public Services (Social Value) Act 2012. URL: http://www.legislation.gov.uk/ukpga/2012/3/ enacted

6. Ley № 142 de 11.07.1994 por la cual se establece el rugimen de los servicios publicos domiciliarios y se dictan otras disposiciones. URL: http://www.alcaldiabogota. gov.co/sisjur/ normas/Norma1.jsp? $\mathrm{i}=2752$

7. Charter of Public Service in a Culturally Diverse Society. Australian Multiculturalism for a New Century: Towards Inclusiveness. National Multicultural Advisory Council. Canberra, 1999. P. 112-118.

8. Guglielmi G.J. Une introduction au droit du service public. URL: http://www.guglielmi.fr/IMG/pdf/ INTRODSP.pdf

9. Duguit L. Les transformations du droit public. Paris : Librairie Armand Colin, 1921. P. xviii.

10. Grout P.A. Private delivery of public services. The Centre for Market and Public Organisation. 
URL: http://www.bristol.ac.uk/cmpo/publications/ publicservices/ppfinal.pdf

11. Савченко А.В. Злочини у сфері службової діяльності та професійної діяльності, пов'язаної з наданням професійних послуг : Науково-практичний коментар до розділу XV Особливої частини Кримінального кодексу України. Київ : Алерта, 2012. 160 с.

12. Кримінальне право України: Особлива частина : підручник / Ю.В. Баулін та ін. ; за ред. проф. В.Я. Тація, В.І. Борисова, В.І. Тютюгіна. Харків : Право, 2015. 680 с.

13. Киричко В.М. Кримінальна відповідальність за корупцію. Харків : Право, 2013. 424 с.

14. Концепція розвитку системи надання адміністративних послуг органами виконавчої влади, затвердженої розпорядженням Кабінету Міністрів України від 15 лютого 2006 року № 90-р. URL: https://zakon.rada.gov.ua/laws/show/90-2006-\% D1\% 80\#Text

15. Закон України «Про адміністративні послуги». URL: https://zakon.rada.gov.ua/laws/ show/5203-17\#Text

16. Палюх Л.М. Зміст поняття «особа, яка здійснює професійну діяльність, пов'язану з наданням публічних послуг» у кримінально-правових нормах. URL: https://www.researchgate.net/publication/ 341105554 Zmist ponatta osoba aka zdijsnue profesijnu dialnist pov'azanu ${ }^{-} \mathrm{z}$ nadannam publicnih ${ }^{-}$ poslug_u_kriminalno-pravovih_normah

\section{Анотація}

Сазонова $A$. О. До визначення змісту поняття «незалежна професійна діяльність». - Стаття.

Статтю присвячено дослідженню значення поняття «незалежна професійна діяльність» у контексті податкових відносин.

Держава цілеспрямовано вживає заходів щодо легалізації майна та діяльності, що підлягає оподаткуванню, в тому числі й діяльності так званих «самозайнятих осіб». Подальше опрацювання проблем оподаткування самозайнятих громадян, у тому числі осіб, які займаються незалежною професійною діяльністю, забезпечить легітимізацію цієї діяльності та захист їніх інтересів, а також забезпечить зростання державних доходів загалом та рівня життя зокрема.

Відповідно до п. 14.1.226. Податкового кодексу України, особи, які здійснюють незалежну професійну діяльність, є самостійною підгрупою самозайнятих осіб. До категорії самозайнятих також належать фізичні особи-підприємці. У цьому випадку визначальними ознаками самозайнятої особи як платника податків $€$ те, що зазначена особа не є найманим працівником у разі здійснення такої підприємницької чи незалежної професійної діяльності. Незалежна професійна діяльність визначається як участь особи в науковій, літературній, художній, освітній чи викладацькій діяльності, діяльності лікарів, приватних нотаріусів, приватних виконавців, юристів, арбітражних керуючих (розпорядників майна, керуючих санацією, ліквідаторів), аудиторів, бухгалтерів, оцінювачів, інженерів чи архітекторів, діяльність осіб, що займаються релігійною (місіонерською) діяльністю, іншою подібною діяльністю, за умови, що така особа не є працівником або фізичною особою - підприємцем (за винятком випадків, передбачених пунктом 65.9 статті 65 Податкового кодексу України) і використовує найману робочу силу не більше чотирьох осіб.

Таким чином, відповідна діяльність характеризується двома обов'язковими ознаками: незалежні- стю, тобто відсутністю підпорядкування з точки зору трудового законодавства, можливістю встановлення трудових відносин з обмеженою кількістю осіб, а також відсутністю іншого податкового статусу (тобто податкового статусу фізичної особи - підприємця); професійністю, тобто спеціальною освітою або підготовкою особи, що її здійснює, в т.ч. й отриманням за необхідності необхідних дозволів.

Незалежна професійна діяльність класифікується як така, що пов'язана з наданням публічних послуг та іншою незалежною професійною діяльністю. Перелік видів незалежної професійної діяльності в обох категоріях не є вичерпним. Це, зокрема, свідчить про необхідність законодавчої систематизації публічних послуг, а також врегулювання порядку і стандартів їх надання. Ще існує нагальна потреба в більш чіткому розмежуванні правового та, зокрема, податково-правового статусу осіб, що здійснюють незалежну професійну діяльність, і фізичних осіб підприємців.

Ключові слова: незалежна професійна діяльність, податковий статус, публічні послуги.

\section{Summary}

Sazonova $A$. $O$. To define the content of the concept of "independent professional activity". - Article.

The article is devoted to the study of the meaning of the concept of "independent professional activity" in the context of tax relations.

The state purposefully takes measures to legalize property and activities that are subject to taxation, including and the activities of so-called "self-employed citizens". Further elaboration of the problems of taxation of self-employed citizens, including persons engaged in independent professional activity, will ensure the legitimization of their activities and protection of their interests, as well as ensure the growth of state revenues in general and living standards in particular.

According to item 14.1.226. According to the Tax Code of Ukraine, persons engaged in independent professional activity are an independent subgroup of self-employed persons. The category of self-employed persons also includes entrepreneurs. In this case, the defining features of a self-employed person as a taxpayer is that the said person is not an employee within such entrepreneurial or independent professional activity. Independent professional activity is defined as the participation of an individual in scientific, literary, artistic, artistic, educational or teaching activities, the activities of doctors, private notaries, private performers, lawyers, arbitration managers (property managers, reorganization managers, liquidators), auditors, accountants, appraisers, engineers or architects, a person engaged in religious (missionary) activities, other similar activities, provided that such person is not an employee or individual entrepreneur (except as provided in paragraph 65.9 of Article 65 of the Tax Code of Ukraine) and uses hired labor is not more than four individuals.

Thus, the relevant activity is characterized by two mandatory features: independence, as a lack of subordination in terms of labor legislation, the possibility of establishing employment relationships with a limited number of persons, as well as the absence of other tax status (tax status of an entrepreneur); professionalism, as a special education or training of the person performing it, including and obtaining the necessary permits if necessary.

Independent professional activity is classified as that related to the provision of public services and other 
independent professional activity. The list of independent professional activities within both categories is not exhaustive. This indicates the need for legislative systematization of public services, as well as regulation of the procedure and standards of their provision. There is also an urgent need for a clearer distinction between the legal and, in particular, the tax and legal status of selfemployed persons and entrepreneurs.

Key words: independent professional activity, tax status, public services. 